\title{
‘Literary’ Analysis of State (Media) Terrorism in Orwell's 1984
}

\author{
Alić $S^{*}$ \\ University North, Croatia
}

*Corresponding author: Sead Alić, University North, Trg dr. Žarka Dolinara 1, 48000, Koprivnica, Croatia, Tel: 00385989828592; Email: salic@unin.hr

\section{Research Article \\ Volume 2 Issue 2}

Received Date: March 27, 2019

Published Date: April 17, 2019

DOI: $10.23880 /$ phij-16000117

\section{Abstract}

We are constantly starting new wars in our search for peace. In a battle, we hope for peace that will allow us to prepare for the final war. We produce more and more weapons. There are already so many arms that they cannot be fathomed by human thought. Due to declaring the war on terrorism, with any deviation from Big Brother's opinion considered as terrorism, the war has become a means for bringing opinions into uniformity. Since the whole peoples have to follow this opinion, it has been dubbed democracy. The war on terror has become the war for political conformism that bears the name of democracy. But unlike Athenian democracy, in which women and slaves could not participate, nearly no one participates in it today. Democracy is a logo on bombers, drones, corporate platforms and bottles of diluted sugar sold all over the planet.

Keywords: Orwell; Totalitarianism; Terrorism; Big Brother; Media; Fear; Love

We have not read many books we claim to have read. We mention their titles, the names of their authors, the symbolism they employ. We turn them into symbols whose meaning we do not fully understand. We diminish the depth, beauty and power of those books' messages and reduce them to words, syntagms and phrases that are forced on the ignorant as if in a broken telephone game or through a viral effect. This makes life easier for the ignorant, who remain unaware that the essence of the problem emphasised in a book is still omnipresent.

Orwell's 1984 is one of such books, a book that "everybody has read". Nevertheless, it gradually fell into oblivion after the calendar year 1984. This was perhaps an understandable consequence of the strategy (referred to in the novel) involving the obliteration of historical facts, the changing of documents and the rule that only the most recent records of facts should be relevant. "Everything - to cite Orwell - faded away into a shadow- world in which, finally, even the date of the year had become uncertain"

However, we did not take the novel 1984 as seriously as we should have ${ }^{2}$. This is why I believe that we must analyse that year, which is now behind us, so that we can understand what is happening to us. To put it more precisely, our 1984 is more terrible and ominous than we could have imagined.

\footnotetext{
${ }^{1}$ Orwell, George,1984, published in the Croatian translation by Alfa, Zagreb, 2008. The original quotation is retrieved from 1984, Everyman's Library, Germany, 1992, p 44.

${ }^{2}$ In order to understand this great novel, we have to read Orwell's other works, such as Why I Write and Other Essays, Animal Farm, Down and Out in Paris and London and Homage to Catalonia. If we do not read them, we could fall into a trap of characterising Orwell as a stern critic only of Soviet-type totalitarianism. We should keep in mind that he is a critic of every form of totalitarianism and that his criticism, rather than being political, stems from his own life experience.
} 
What is happening to us?

The world order of fear has been established. A world power has declared war on the world under the guise of fight against terrorism. Imperialism and neo-colonialism have entered their final phase, openly advocating inequalities and imposing force as the only means of dialogue. The election of the American president is the election of a world imperator whose morning digestion affects the balance of war and peace in a small country somewhere in the world. The high-ranking Party officer O'Brien proclaims in 1984: "Obedience is not enough. Unless he is suffering, how can you be sure that he is obeying your will and not his own? Power is in inflicting pain and humiliation...A world of fear and treachery and torment, a world of trampling and being trampled upon, a world which will grow not less but more merciless as it refines itself ${ }^{\prime 3}$.

We are trying to love Big Brother. He has become more powerful and more terrifying and more flexible. His faces change, but each wears a fake smile and pretends to be serious. Rather than revealing its true nature, Big Brother's face follows the photographer's instructions ${ }^{4}$.

Love towards Big Brother had been prepared for a long time. It was born together with the illusion that something that is commonly owned, or that should and could be commonly owned, belongs only to me. The limitations of my private property have become my own limitations. The system that promised me the inviolability of my property was my prison. The walls of that prison were the seductive and manipulative mass media ${ }^{5}$.

After having been tortured, the hero from 1984 realises that he has to try to love Big Brother in order to be able to kill him and free himself from his misery. We also have to love Big Brother. The industry of politics that backs him up has enabled us to change his appearance giving us the dramaturgy and the illusion of choice. We more or less truly believe that we love a certain personality of the industry of politics. We love one big

${ }^{3}$ Orwell, George, 1984, published in the Croatian translation by Alfa, Zagreb, 2008. The original quotation is retrieved from 1984, Everyman's Library, Germany, 1992, pp: 279.

${ }^{4}$ For more information about this relation see: Alić, Sead, Istina iz fotografskog stroja (Truth from the Camera), Kultura No. 132, Suvremeni žurnalizam, - trendovi, dileme, izazovi, ISSN 0023-5164, published by Zavod za proučavanje kulturnog razvitka, Belgrade, 2011 (pp: 249-269).

${ }^{5}$ For more information on mass media as an open prison see: Alić, Sead, MASMEDIJI, zatvor bez zidova (Mass Media, a Prison without Walls) ISBN: 978-953-56314-2-2, Centar za filozofiju medija, Zagreb, 2010. brother because he represents a stereotype of male attractiveness; another because of his rebellious gaze and still another because of his composed gaze that does not even reach us. During the recent decades, Big Brother has also been given a female form. Male proles are especially happy with that: if they are not or have not been listening, they now at least have something to watch. Besides, it is easier to love the female Big Brother. This, somehow, makes death sweeter.

Every death is the acknowledgment of an imbalance in the organism, nothing but the final corporal acknowledgment of surrender. Death gives meaning to our efforts to bring a little bit of light into our sombre lives, and the only light that is available to us is the artificial light of a leader, a homeland, a party, a nation. We no longer have Anaxagoras' strength to point our finger up towards the sky at the mention of our homeland.

In order to dissuade any occasional criticism of Big Brother, the industry of politics has manipulated the truth and in the macrocosm of politics created the microcosm of a show programme in which proles watch other proles twenty-four hours a day. The programme has been named Big Brother, after its godfather. The stratagem of the industry of politics is based on the proven facts that the best place for a thief to hide is a legal clause, that laws are adopted by those trying to protect themselves and that the biggest secret is the one declared as a well-known but unaccepted truth.

The programme programs a programme used for programming a program within people. We unconsciously accept value systems brought to us by the dictatorship of repetition. Politics is openly laughing at us, the small fish, in our faces, forcing us to form our own statements about our weaknesses.

While proles are watching other proles, the industry of politics is inserting cameras and microphones into our laptops, TV sets, cell-phones and other devices uses by proles to incriminate themselves in front of the councils authorised for wiretapping and observing proles. The year 1984 has been surpassed. Nowadays proles rush to companies selling telescreens so that they could buy devices for wiretapping and observing themselves. In return they can watch recycled media garbage, X-rated movies and they can see Big Brother's transformations. The industry of politics has employed the best experts to construct microphones and cameras that record even when they are turned off. That makes it easier for proles to turn themselves in. The process is automatic. 


\section{Philosophy International Journal}

Every reference to science in the world where science is threatened and endangered has to be critically examined. Are we creating stupid authority figures, authoritative personalities, or are we thinking? Are we thinking openly and are we ready to face failure, or are we just repeating a designated mantra? The science of proles has to be serious, dull, empty and postmodern. Every request for change is punished. The army, the police, the corrupt judiciary, reporters scared for their lives, intellectuals in the society of containers, excommunication from life, acquaintances and friends looking away - take your pick.

Big Brother expresses his closeness by being distant. To be distant means to let the others release their love and start craving the object of their affection. Big Brother no longer flies over the heads of his followers in a helicopter. His powerful eye watches from divine satellite heights. Omnipresent, but invisible, this eye has all the required divine attributes. Proles have to interpret this fact correctly, and the only correct interpretation is that Big Brother is closer to each of us than our own breath.

They say that God is dead. For one king to live another must die. For the power of the satellite eye to gain its full force the Eye of God must be obliterated. Zeus' lightning bolts have become more efficient and precise now that Zeus is long gone.

If someone needs to be eliminated, but in a way that everyone can witness it so that Big Brother's fearlessness, precision, efficiency and divine vengefulness can be demonstrated, a small agile drone with destructive explosives is sent to kill rebels, but also to punish all those who let themselves be in the presence of a person they should have guessed will eventually fall victim to Zeus' anger.

Nowadays we produce weapons that decide by themselves who they are going to kill. True professionals. First they kill, then they question...

The Thought Police has also completed its weapon arsenal. Instead of examining people's thoughts it has developed a profession that can form their opinions. Thought prevention is exercised in the same way as health prevention. Self-reporting, self-recording and devices that broadcast and record at the same time - that is, record even when they are turned off - are extremely helpful in that process of cultivating positive thoughts. The ecological times have shown that it is possible to cultivate a thought perfectly loyal to Big Brother, which needs to be controlled only occasionally and routinely (only to verify if it is still functioning).

Belief in the political thought gave rise to belief in the mathematical organisation of thoughts, which in turn gave rise to belief in the technical and technological definition and organisation of thoughts. A technically organised world no longer needs thoughts. We have reached the bottom and we now have to question what the medium with which we intended to conquer the world has turned into. For the purpose of the technical takeover of the world we have created a monstrous system of imprisoned thinking. The self-confident media of logic, grammar, words and thoughts have become the means of our mental and political hara-kiris.

The immaculate thought is cultivated with the help of new speech. In order to attain purity new speech has named itself Newspeak. Newspeak is studied by language doctors, specialists in detecting the symptoms of the old speech, known as Oldspeak. The progress made in relation to the vision of 1984 also stems from the fact that every new Big Brother introduces its own Newspeak. This creates a social dynamics and allows for the detection of deviations in approaches to language (which only reflect deviations at higher levels). In addition, Newspeak renders thinking impossible because nobody thinks in a language he has to intensely think about while speaking it. It is easier not to think.

The language of thinking has given way to the language of adaptation.

We are constantly starting new wars in our search for peace. In a battle, we hope for peace that will allow us to prepare for the final war. We produce more and more weapons. There are already so many arms that they cannot be fathomed by human thought. Due to declaring the war on terrorism and slapping the label of terrorism on anything not in line with Big Brother's opinions, the war has become a means for bringing opinions into uniformity. Since all peoples have to follow these opinions, they have been dubbed democracy. The war on terror has become the war for political conformism that bears the name of democracy. But unlike Athenian democracy, in which women and slaves could not participate, nearly no one participates in it today. Democracy is a logo on bombers, drones, corporate platforms and bottles of diluted sugar sold all over the planet.

This is why big leaders, Big Brother's main collaborators, have their photographs increasingly more often taken with machine guns, in military uniforms, with 


\section{Philosophy International Journal}

soldiers, in army tents and during military drills. They are getting their peoples accustomed to preparations for new wars in the times of peace.

In order for those photographs to be widely disseminated, we need a military-minded, obedient and robotic journalism. It has to be precisely guided. Authors are killer drone-robots, controlled from afar.

The media adore the photographs of big leaders with weapons. They always seem to find themselves in a place where big leaders are hugging or caressing a machine gun or long cannon barrel. They especially appreciate women as big leaders. The eroticism of a cannon barrel and a woman with a machine gun boosts the morale of the people condemned to suicide. Published day after day, such photos create among people an expectation of war, absolution and catharsis that will bring a blood-soaked end to the drama perpetuated by the warmongering mass media.

Newspeak has narrowed down the meaning of the word freedom. Nowadays we cannot understand this word without the explanatory attributes. For example, the well-known syntagm "the freedom of the market" signifies more than freedom itself. It implies efforts to sell sugar water in the parts of the world and to the nations without a tradition of drinking it. It also signifies the freedom of advertising sugar water with the help of a global screen. Finally, it signifies the freedom of employing cheap labour force from third-world countries to mix water and sugar and create the favourite drink of people all around the world. The drink is, of course, partly poisonous, but Big Brother has to prevent overpopulation, people have to die of something eventually. Those who drink sugar water will not have to resort to suicide. Dead as they are, they will end their existence by drinking Big Brother's neocolonial poison.

In fact, we made a wrong turn a long time ago when we failed to realise that a thought could be a trap. Like media intermediation, which, having developed from eidos, geometric regularity, leads to regularity without man - the thought is today overcome by the futility of its own efforts. Everything is ruled by appearance appearances govern our lives.

Big Brother has created big leaders after his own image by osmosis. Every big leader has special buildings and institutions where his images are multiplied and disseminated to the non-existing public. The images are published, but there is almost no one to write critically about them. The minority that is bold enough to do so is an "expatriate" minority in its own country. Such citizens, as a rule, gradually give up, move away or change their opinions. Those who change their opinions generally become self-proclaimed experts and, based on their merits, reach the highest ranks of the Thought Police.

The world is bombarded by the little stories of postmodern tadpoles.

Different degrees of slavery have been labelled freedom of choice. Everyone can choose whether to watch or listen to lies propagated by the truth-declaring means of public communication. If you do not like a voice professing a lie under the guise of truth you can change the channel and choose a more soothing voice or a prettier face. Garbage is no longer thrown away, but it is recycled into television programme. Everybody is in it, because the production of a programme in which those who want to watch themselves participate is the cheapest option. It is also in every respect the closest to the idea of participating in the idea of the big leader's programme.

The fact that there is no difference between the behaviour of the North Korean and the American leader only proves that there is actually no difference between North Korean parades and American democratic election parades.

Knowledge creates enemies. A state that wants to manipulate a docile mass will declare itself the state of knowledge. Those who fall for that will make many enemies. Especially among people who know that ignorance is power and that they have been chosen for the highest positions only because they did not let themselves be deceived by the ideological lie. There is no point in having in the ruling classes those who are susceptible to being deceived by the ideology of those same classes. Those who cannot comprehend the fundamental essence of hypocrisy in the times after the year 1984.

Liberation can only be attained by recognition. Nowadays, hypocrisy is the fate of intellectuals. We are so civil, scientifically oriented, methodical and meticulous in maintaining the illusion that this is who we really are.

The science industry has discovered the copy/paste method, which is usually only used by experienced members at the top. This method allows them to gain more knowledge while remaining ignorant. Since ignorance is power, they retain their positions of power. Using the copy/paste method. 
Academic octopuses have developed hierarchies in which only the adherents of the copy/paste method can persevere. The others do not understand this method. The scientific copy/paste method 6 .

The answer to the question what science is used to be: a method. The contemporary knowledge industry has realised that the designation of science as a method is only the mystification of something that only seemingly guarantees objectivity and results. In addition, due to the insistence on a method, many scientific studies only explained the method applied, no matter what the subject was, with their findings stating that it was scientific. Nobody remembered what had actually been researched. The science industry went a step further. If the method has made all research meaningless, then there is no need for research at all. All results are known anyway, and every piece of research is initiated in order to prove a thesis. The Thought Police was for years searching for a scientific paper that would prove that it did not prove its initial thesis. Finally, a decision was made: from that moment on, the results of previous research were to be plagiarized. This gave an advantage to those who were closer to the top of the hierarchy. They got their stomachs full and put on black togas and golden chains. They looked like Herzegovinian tradesmen and Arab students, but they did not care.

One of the theses put forward during the Enlightenment with the aim to differentiate between basing a society on religion and potentially basing it on reason was supported by the argument that religion was a product of fear. The philosophers of the Enlightenment saw fear of Hell, fear of sin, fear of immoral acts, of adultery, murder and all the retributions of an angry God as a means to tame the mass that was being governed. The ecclesiastical hierarchy had, and still has, the strongest argument on its side - Big God could punish all the believers according to its instructions.

Orwell's Ministry of Love learned from the philosophers of the Enlightenment, which is why its love is enlightened. It provides fear that those philosophers wrote about and warned about. Even if the objective is not the same, the means is. Fear has been reactivated and it performs its cohesive function. However, the place previously held by religion is now occupied by love. The hierarchy of priests in their strange silk robes has been replaced by the hierarchy of the Ministry of Love. Religion is no longer transcendental - instead of Big God, we are now afraid of big leaders and Big Brother. Big Brother is invisible. Therefore, love is shown to the party, on Earth, the party being Big Brother's earthly body: "The Party seeks power - speaks Orwell through his character O'Brien - entirely for its own sake. We are not interested in the good of others; we are interested solely in power. Not wealth or luxury or long life or happiness: only power, pure power...We are different from all the oligarchies of the past, in that we know what we are doing. All the others, even those who resembled ourselves, were cowards and hypocrites. The German Nazis and the Russian Communists came very close to us in their methods, but they never had the courage to recognize their own motives... We are not like that. We know that no one ever seizes power with the intention of relinquishing it. Power is not a means, it is an end. One does not establish a dictatorship in order to safeguard a revolution; one makes the revolution in order to establish the dictatorship. The object of persecution is persecution. The object of torture is torture. The object of power is power"7.

By living in fear we in fact indirectly feel love. Love towards Big Brother cannot be expressed in any other way but through fear. Fear is the most realistic, the safest and the most complete affirmation of a person's trust in Big Brother. Feelings are fleeting, no love is eternal, but fear can accompany man from birth until death.

Building on this line of thought in an ironic discourse, we could add: throughout history, people have been doing many inappropriate things in the name of love. The Trojan War was started because of love; love was the reason why the Greek philosophy was adopted by homosexuals. Did Romeo really have to destroy Juliet, and only on account of love? Abelard was cruelly punished because he dared to love Heloise. Big leaders free us from our need for love and from stupid actions we undertake in the name of love. Fear is a sufficient guarantee for big leaders that their followers will refrain from foolish acts.

The philosophical fear of misunderstanding technology and the fact that the human quality in media intermediation is no longer questioned have resulted in a hypocritical love towards lifelines in the form of armchairs modelled after the backsides of people who wish to present themselves as thinking individuals.
${ }^{6}$ For more information about the copy/paste method see: Alić, Sead, Copy/paste kultura, od Mehaničke mlade do copy/paste culture (Copy/Paste Culture: from the Mechanical Bride to Copy/Paste Culture), Filozofska istraživanja No. 109, 2007, pp: 63-74.

\footnotetext{
${ }^{7}$ Orwell, George,1984, published in the Croatian translation by Alfa, Zagreb, 2008. The original quotation is retrieved from Orwell, George, 1984, Everyman's Library, Germany, 1992, pp: 275-276.
} 


\section{Philosophy International Journal}

It was a long time ago when Marx voiced his desire for heavenly problems to descend to Earth and for earthly relations not to rise to the heavens. This has now come true. Big Brother, as a supreme authority, is a man who does not aspire to divine attributes. He does not proclaim earthly problems to be heavenly, nor does he make people believe in the transcendental. With his feet firmly on Earth, drawing his strength from fear produced by his Thought Police, Big Brother is safe. Love is a thing of the past, it existed in the times when an individual was at the mercy of social movements, when people lived in an illusion of peace, thinking that the freedom of choice entails love.

Socialist five-year plans have been replaced by western ones. States have become corporations. Their main concern is not justice or the well-being of their citizens, but their corporate year-end balance sheets: desire for profit of the biggest thieves is presented under the guise of national pride. The whole nation wearing the same football jersey symbolises our unity in lie. We all love that lie because it shows us that lie can win too...

Big Brother is broadcasted by the contemporary media and modern media churches, which make sure that his ideas reach all parts of the world and every living soul on Earth. His masses are the rituals of hate that were at first aimed at Goldstein, his arch-enemy, and later developed into an exquisitely dramatized news reel. This is all framed by the syntagm "informational programme", which makes it clear to all participants that they first have to attend informational interviews. The purpose of those interviews is to assess how afraid they are. The level of fear defines their ability to worship earthly values instead of transcendental ones.

The mass media broadcast the catharsis of hate.

Two Minutes Hate have spread through our bodies and extended into five to ten minutes per hour. Special hate channels transmit the so-called news for twenty-four hours a day. In case you run out of hate you can simply turn on Big Brother XXXL channel (on your watch, for example) and obtain all the content necessary for further functioning.

Throughout history, philosophy has been playing hide and seek with its own idea of god. God has been conceived as the unmoved mover, as the thought of thought, as a substance, as nature... The philosophical god is described in such abstract terms, it is so vague, camouflaged, concealed and referred to by many different, almost unrecognisable names, that it is no wonder that some historical individuals have adopted those definitions. Man decided to become God and has succeeded in becoming one only in the age of mass media releases. What are stone slabs and the script compared to satellite devices and mass media communication? What is monotheist religions compared to single-party systems? What are transcendental gods compared to our own domestic, familiar, warm, dressed-up, photo shopped and smiling human gods?

Big Brother's state is pure anarchy. It advocates fight against the cruelty of every law, even the one on which states as "dungeons for the people" are based on. Big Brother, a visionary, has introduced into our lives a society that does not need any laws. In an anarchistic turn of phrase, nothing is illegal. Citizens can do what they please because they know they will be rewarded for that by the Ministry of Love, Ministry of Truth or some other institution that makes sure that we constantly think about and feel fear and that it remains deeply ingrained in our souls.

Loopholes can exist in law, but not in fear. There is no lack of proof that laws can be easily circumvented. Fear is the only real law, a law that makes any other law unnecessary and compels people to follow Big Brother out of pure love. Chips in our bodies, drones above our heads, cameras, microphones and entertainment industry devices strongly remind us of the universal value of a sincere and deep love.

Is philosophical prose the world's Trojan Horse? Is man's original sin actually an escape into an exoteric, technical and empty knowledge, which gives birth to an exoteric, technical and empty man? How much have we lost by trying to escape the mythical, the poetic and the religious (in their esoteric sense)?

The book 1984 drew attention to the role of agents provocateurs and their soon to be achieved significance. O'Brien's character is only roughly outlined compared with masterfully created officers with double and even triple personalities. The age of hypocrisy will turn man into a highly professional actor, capable of playing a believer in an idea, a convert, a conspirator, a rebel in disguise, an idealist hiding behind the commonplace phrases of a party, etc. The age of hypocrisy has become the age of trading information about people and their opinions, political orientations, intentions... The advocates of certain orientations are selling their souls in the streets, under the tables, in party members' offices, anywhere. Left and right no longer mean anything, at least as concerns material profit and jobs to be gained by crossing from one side of the street to the other. 


\section{Philosophy International Journal}

Nationalists are infiltrating themselves into the political left, while the ones on the left are becoming devout nationalists, but in reality, what they both have in common is only their readiness to showcase their talent as actors.

After having explored the continents, the sky and the universe, we have to conquer history.

Fighting for a better past is a strategic interest of the hierarchy that knows is has no future. As long as history continues to be changed, the existence of that hierarchy is ensured. An unambiguous and firmly defined history would open possibilities for heretic thoughts and comparisons. Therefore, year after year, all countries ruled by political hierarchies devote more coverage in proles' programmes to changing the past or to fighting against those who have been changing it. The fact that those are one and the same people, one and the same parties (possibly with different names) means nothing. The dialectics of change initiated by the top is in action. The changes coming from the top have a dialectic and historical purpose.

Proles of all countries - you deserve better philosophers!

In conclusion, the following should be emphasised: the word "literary" in the title is put in inverted commas because this paper does not provide a literary analysis. Nor does it analyse Orwell's dystopia in the context of similar literary works that foresaw a bad future. Its aim is to demonstrate the power of current systems of seduction and manipulation used by politics, corporations and media, which is more horrifying than any literary dystopia.

Our experiences in today's world are more awful than Orwell, Huxley, Burgess, Bradbury, Zamyatin and other dystopian writers predicted them to be. The turning point suggested by this paper involves raising the awareness of the need to address the dystopian ideas that have already been realised in the societies we live in. Therefore, it focuses on the critical analysis of the system of media intermediation, that is, on the philosophical and literary analysis of the reality that requires new interpretations of the dystopian literature.

We are inhabitants of living dystopias. Not only are they more powerful and imaginative than any foreboding literary dystopia, but they are also considerate, restrained, seemingly civil and always polite - hidden behind the scenes.

Our task is, among other things, to analyse them as they were predicted in fiction. This will help us to understand them better, and better understanding is a precondition for everything else.

\section{References}

1. Alić S (2011) Istina iz fotografskog stroja, Kultura No. 132, Savremeni žurnalizam - trendovi, dileme, izazovi. Zavod za proučavanje kulturnog razvitka, Beograd, pp: 249-269.

2. Alić S (2010) MASMEDIJI, prison without walls. Centar za filozofiju medija, Zagreb.

3. Alić S (2007) Copy-paste kultura, od Mehaničke mlade do copy-paste kulture, Filozofska istraživanja 28(1): 63-74.

4. Orwell G (1949) 1984.

5. Orwell G (2008) 1984. Alfa, Zagreb.

6. Orwell G (1983) Kataloniji u cast. August Cesarec, Zagreb.

7. Orwell G (1983) Životinjska farma, August Cesarec, Zagreb.

8. Orwell G (1983) Nitko i ništa u Parizu i Londonu, August Cesarec, Zagreb.

9. Orwell G (1983) Zašto pišem i drugi eseji, August Cesarec, Zagreb. 